\title{
複合視覚センサによる高精度寸法・形状計測
}

$\begin{array}{lllll}\text { 正員 岡 田 三 郎 } & \text { (中国工試) } \\ \text { 正員 住 本 哲 宏 } & \text { (中国工試) } \\ \text { 非会員 宮 内 } & \text { 秀 和 } & \text { (中国工試) } \\ \text { 正 員 山 } & \text { 本 秀 樹 } & \text { (岡山大) }\end{array}$

\section{Dimension and Shape Measurements with High Accuracy Using Composite Image Sensors}

Saburo Okada, Member, Tetsuhiro Sumimoto, Member, Hidekazu Miyauchi Non-member (Govern. Inst., Chugoku), Hideki Yamamoto, Member (Okayama University)

A new composite image sensor system is proposed. Two different type image sensors, area and line sensors, are used effectively to make dimension and shape measurements with high accuracy. An area sensor is used to obtain a whole image of the object at an accuracy of $1 \mathrm{~mm}$ and to pick up regions which are necessary to measure shapes and position of edges or holes, then a line sensor is used to obtain a high resolution image of picked-up regions by rotating and scanning the line sensor at an accuracy of $0.1 \mathrm{~mm}$. This sensor system has an advantage that the acquisition time of image input is shortened and that the amount of data is much reduced as compared with an image input system using a line sensor only.

Experimental results show that this composite image sensor system is available in the field of not only parts' dimension and shape measurement but also three-dimensional geometrical measurement.

キーワード：センサ, 視覚, 画像処理, 形状計測

\section{1. まえがき}

近年, 画像計測技術の生産工程への導入には目覚し いものがあり，自動化，省力化の有力な決め手として 注目されている。しかしながら，現在用いられている 工業用カメラを用いた画像処理システム(1)の解像度は 綐横 500 画素程度（視野サイズの $0.2 \%$ の精度）が主 流となっており，生産工程で要求される $0.1 \mathrm{~mm}$ の精 度で寸法や形状の計測を行おうとすると，視野サイズ はわずか $5 \mathrm{~cm}$ 程度に狭められ, 対象物全体の画像を 一度に撮り込めなくなる。従って，カメラあるいは対 象物を精密に移動する装置が必要となり，画像計測の 長所である高速性，機動性が失われてしまう。この問 題点を解決する方法としては, 画像入力・処理装置の 解像度 (画素数)を上げることが最も望ましいが, 装置 が特殊で高価なものになるうえ, 高解像度化に伴いデ
一夕量が急增し，処理速度が著しく低下することや多 量のデー夕を高速処理するためにシステムが大形化： 複雑化するなどの問題が新たに発生する。

精度の向上を図る方法として, 佐藤ら ${ }^{(2)}$, 成瀬ら ${ }^{(3)}$ は画素補間, 内㨀, 関数あてはめなどの画像処理手法 を提案している。しかし，広い視野に対して $0.1 \mathrm{~mm}$ の検出精度を安定的に得ることは困難である。このほ かにも，精度を向上しかつ画像入力処理の効率化を図 ったインテリジェント機能を有する画像入カセンサの 開発が行われている( ${ }^{(4)(5)}$ 。有賀ら ${ }^{(6)}$ の極座標方式の力 メラは, ラインセンサを回転させながら画像入力を行 い, 画面の中央付近の解像度を周辺部より数倍高め, 画素数を増加させずに精度の改善を図っている。しか 乙極座標系のため, 座標变換と画素補間処理が必要 こと，場所により精度が異なるなどの点から，寸法・ 形状計測には適しているとは言い難い。 
上記したように，現状では大きな物体を対象とする 高精度で沉用的な画像入力センサに適当なものがな く, 高精度位置決め, 寸法計測用途に画像計測法を導 入するうえでの障害となっている。

著者らは，これらの用途に適した画像入力法を確立 することを目指して，センサフュージョンの考えを参 考にしながら既存の画像入力センサに再検討を加え た。そして, 従来, 単独に使われているエリアセンサ とラインセンサを光学的, 機能的に一体化し, 高精度 化と入力処理時間の短縮化とデータ量の少量化を同時 に満足する複合形の新しい画像入カセンサシステム （以下，複合視覚センサと略記）を開発試作した ${ }^{(7)}$ 。 本方式では，まず分解能の粗いエリアセンサで対象物 全体の画像を高速に撮り込み，エリア画像上で寸法形 状計測に必要な領域を抽出指定する。次いで，指定し た領域内をエリアセンサより分解能が 7 倍高いライン センサを機械的に走查して二次元画像を撮り込み, こ の部分的な高精度画像を用いて寸法形状計測を行う。

本方式と既存のラインセンサを機械走査する画像入 力装置 ${ }^{(8)}$ との相違点は，本方式ではエリアセンサでう インセンサの画像撮り込み領域を制御することによる 画像入力時間の短縮と計測に不用な領域のデータの切 捨てによる処理の高速化，効率化を図ることにより， 沉用の画像処理装置で高精度寸法形状計測を可能にし た点にある。機能面では, ラインセンサ回転機構を新 たに設け, 対象物の姿勢や形状に合せて高精度撮り込 み領域を任意に設定できるように自由度を増し, 画像 入力の効率化と時間短縮を図っている。

以下，第 2 章では試作した複合視覚センサの構造, 第 3 章では画像入力処理部の構成，第 4 章では画像入 力処理法, 第 5 章では具体的な機械部品への適用例を 示し, 提案した画像入力装置の性能と寸法形状計測へ の有用性を明らかにする。

\section{2. 複合視覚センサの構造}

試作した複合視覚センサシステムの外観を図 1 に示 す。本システムは, 画像入力センサ部と画像入力処理 部により構成される。画像入力センサ部では受光部の 形状の全く異なるエリアセンサ（横 512, 縦 490 画 素) とラインセンサ（東芝製 TCD 106 C，一次元 5,000 画素) に同一視野の画像を直接結像させることが 困難なことから，図 2 に示寸光学系を考案した。対象 物は光学レンズ系 $L_{1}$ によって, ラインセンサの受光 面に結像され，また光路途中の電動切換え式のミラ 一 Mによってポリエステル製の白色半透明スクリー ン $S$ 上にも結像される。スクリーン像は裹面から光

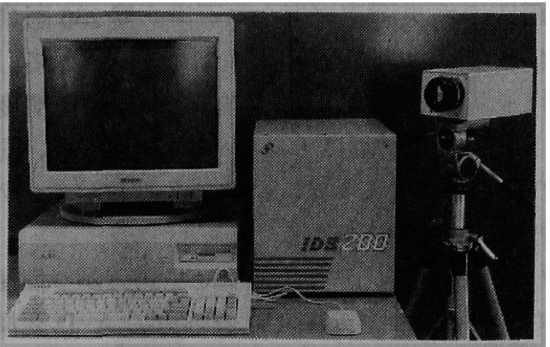

図 1 複合視覚センサの外観

Fig. 1. Outlook of a composite image sensor system.

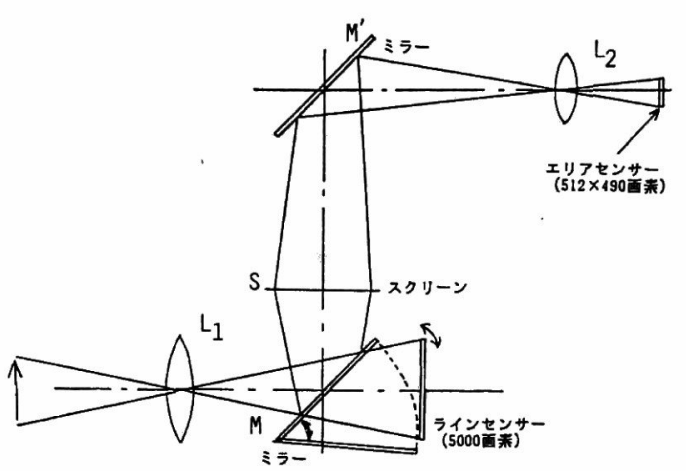

図 2 視覚検出部の光学系

Fig. 2. Optical construction of an image sensing unit.

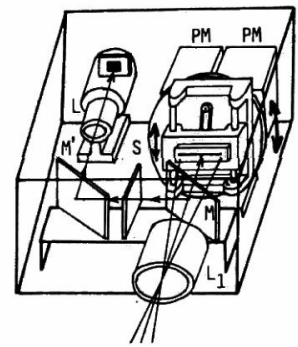

図 3 視覚検出部の構造

Fig. 3. Construction of an image unit.

学レンズ系 $L_{2}$ によってエリアセンサの受光面に縮小 結像され，二つのセンサには同一視野の像が撮り込ま れる。

ラインセンサを用いて高精度の二次元画像を得るた めの, 回転扔よび機械走查機構を図 3 に示す。回転と 機械走査は 2 個のパルスモータPMによって独立に 行われる。回転機構を用いてラインセンサ軸の角度を 対象物の姿勢に合せた後，機械走查を行い二次元画像 が撮り込まれる。図 4 において，ラインセンサは，エ 
リア画像の中央画素 (縦 240 画素, 横 256 画素の位 置）を中心として 元画像を得るための機械走查機構の送り精度は,

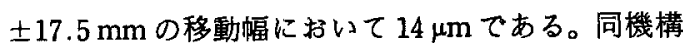
により撮り込まれるライン画像の. 7 画像がエリア画像 の1画索に対応している。

他方, ラインセンサの焦点合せを正確かつ簡便に行 うため, ラインセンサの 1 走查線分の A-D変換（精 度 8 ビット) 後の出力信号画像が, 約 1 秒周期でグラ フィック表示される。図 5 において，画面上側は 8 画 素おきの画素の輝度画像を，また画面下側はセンサ中 央の 500 画素の輝度画像をそれぞれ示している。焦点 合せは，対象物の測定面にテストパターンを置き，図

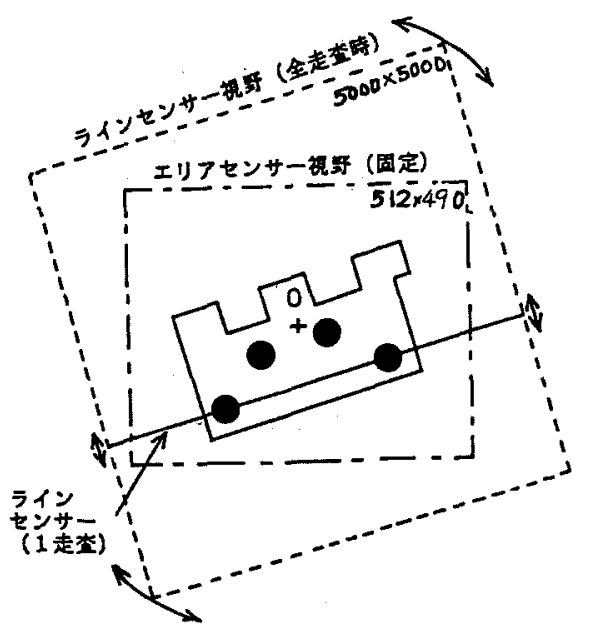

図 4 エリア画像とライン画像の関係 Fig. 4. Relation between area and line images.

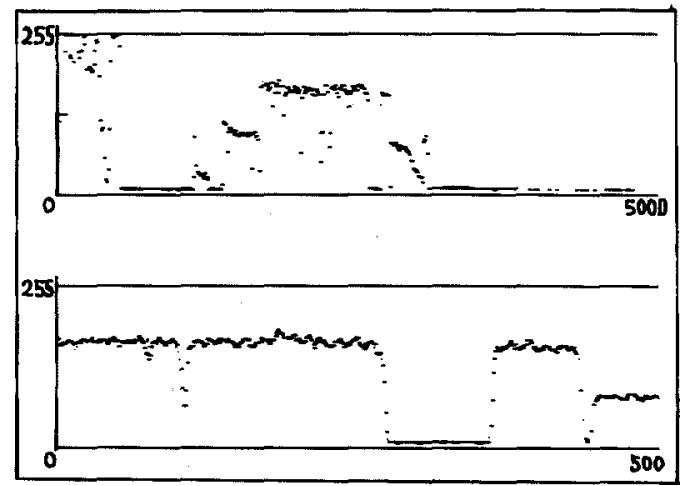

図 5 焦点合せ用画像

Fig. 5. A graphic image for pint adjustment.
5 の下側の画像を監視しながら，A-D 変換後の各画 素の輝度レベルの值が 255 に近づくうに絞りの調臨 を行った後，パターンのエッジ部の立上りの波形が最 も急になるように, 光学レンズ $L_{1}$ のピントを手動 調整することにより行う。

\section{3. 画像入力・処理部の構成}

画像入力・処理部の構成を図 6 に示す。画像入力部 では，エリア画像から対象物の特徵を高速かつ効率良 く抽出するため, 二つのルックアップテーブル（以 下, LUT と略記）を直列に接続し，その間にディレ イ回路を挿入したエリア画像入力部を考案した ${ }^{(9)}$ 。同 回路により，二值化と微分処理，シェーディング補正 と二值化処理など, 二種類の異なる処理が高速に行わ れる。

画像メモリーは 2 メガパイト（最大縦横 1,024 画 素 $\times 16$ ビット）の容量をもち，独自のアドレス指定 方式(9)により，画素構成の異なるエリア画像とライン 画像 (一次元 5,000 画素), ライン合成画像（縦横 512 画素から最大䋛横 1,024 画素) が同一画像メモリー内 で自由に取扱われる。他方，ラインセンサによる高密 度の画像撮り込みと画像転送では多量のデー夕を报う ので，転送処理時間の短縮化を図る必要がある。画像 の入力は図 7 に示すタイミングチャートに従い行われ る。ラインセンサは指定した駆動周波数 $(100 \mathrm{kHz}$ $\sim 2 \mathrm{MHz}$ ) で駆動され，一定周期（=5,000/駆動周波 数, $1 \mathrm{MHz}$ の場合, $5 \mathrm{~ms}$ ) で電荷の蓄積と読み出し が繰返し行われる。ラインセンサ出力ビデオ信号は, A-D 変換後, イメージバス (42 ns/byte) を経由し て1ライン 5,000 画素分が画像メモリーのバッファ領 域（No.1 または No.2）に交互に高速転送される。 そして, 片方のバッファ領域への画像転送中に, 他方 のバッファ領域の画像データ中の指定領域の画像デタだけが, VMEバスライン（350 ns/byte）を経由し

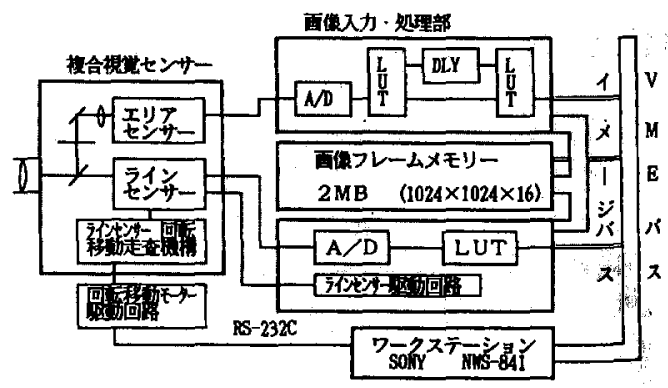

図 6 画像入力好理部の構成

Fig.6. Construction of image input and processing units. 


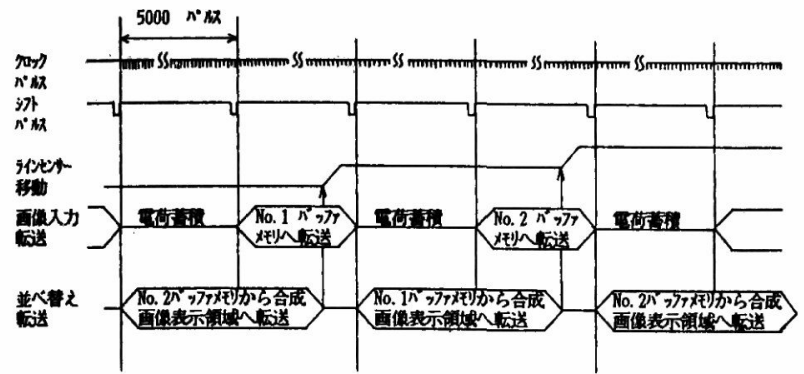

図 7 画像入力のタイミングチャート

Fig. 7. Timing chart of image input.

て画像メモリー内のライン合成画像表示領域に転送さ れる。このように二つのバスラインと二つのバッファ メモリーを用いて同時平行処理を行うことにより，デ 一夕処理時間は従来比 $2 / 3$ に短縮された。

\section{4. 画像入カソフトゥェアの構成}

複合視覚センサを用いて，寸法・形状計測を行うた めの画像入力法を以下に示す。

モード 1 は, 対象物上の二点間の寸法や距離の計測 を目的とする。エリア画像上で測定点を二箇所カーソ ルで指示すると, 二点を結ぶ直線の傾きが計算され， ラインセンサ回転機構により, センサ軸はその角度と 位置に設定される。この回転機構により, 測定点がエ リア画面のどのような方向と位置にあっても，機械走 査領域の大きさと測定時間は常に一定となる。図 8 の エリア画像上には, 白枠で示す縦 18 画素, 横 36 画素 の領域が 2 箅所に表示されるので，その位置を確認し た後, ラインセンサによる画像の撮り込みを行うとエ リア画像の下側に縦 126 画素, 横 252 画素の大きさで 撮り込み画像が 2 秒以内に合成表示される。この合成 画像内の各画素の位置は画像メモリー内部では図 4 に 示す綐横 5,000 画素の座標空間内の座標値として保存 されているので, 合成画像上の各穴の中心をカーソル で指示することにより二点間の距離（図中の DIST の值) が画素数で求まる。実寸法はこの画素数に換算 係数 (mm/pixel) を掛けることにより求められる。

モード 2 は, 寸法形状計測を行う領域をエリア画像 上の任意の場所に複数個指定し, それらの領域をライ ンセンサで精度良く撮り込み, 部分的な高精度画像を 用いて寸法・形状計測を行うことを目的とする。撮り 込み領域数は 1 简所から 25 箇所まで指定でき, ライ ン合成画像の大きさは, 綐横 $512 \times 480,512 \times 1,024$, $1,024 \times 512,1,024 \times 1,024$ 画素のいずれか一つを選択 する。画像入力時間は画面の大きさ, 領域の数と位置

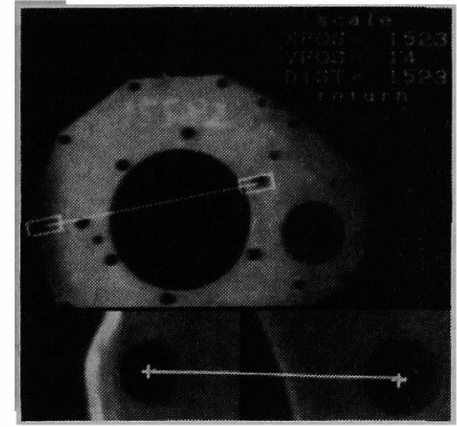

図 8 ライン合成画像 (モード 1)

Fig. 8. Example of a line scanning image (mode 1).

によって異なるが，10 秒以上要している。撮り込み 方形領域は, ライン合成画像を領域数で等分割した大 きさに自動設定される。ライン合成画像にはエリア画 像で指定した方形領域の高精度撮り込み画像が指定し た番号順に切り貼りして表示されている。各領域内の 画素の座標値は，モード 1 と同様に綐横 5,000 画素の 座標空間における值で示され，寸法形状の計測はその 座標値に基づいて行われる。ここで, 部品の寸法計測 においては，同種の部品のあらかじめ指示された箇所 の寸法を計測する例が多い。従って，エリア画像にお いて高精度撮り込み領域を毎回指定していると画像入 力に時間と手間がかかる。そこで，既知の部品につい ては，高精度撮り込み領域の位置と測定パラメー夕を あらかじめ登録保存しておき, 計測時には, 部品の登 録番号を指定すれば，読み取り領域が自動的に設定さ れ，すぐに高精度画像の撮り込みが行える。

\section{5. 本システムの性能と機械部品への適用例}

本システムのセンサ軸（副走査）方向の精度は，ラ インセンサの画素の製作精度に依存する。一方，機械 走查 (主走查) 方向の精度は, 機械走査機構の機械的 な精度（送り精度と平行度）に依存する。回転機構は 機械走査中は固定されているので精度には影響しな い。格子パターンを用いた性能試験の結果，画像の撮 り込み誤差はセンサ軸方向では，1画素以内，機械走 査方向では， \pm 1 画素であり，ほほ良好な性能を示し た。なお, 使用する光学レンズによっては画面周辺部 に光学ひずみが発生し, 精度低下の原因となる。

本システムの具体的な適用例として, 機械部品の穴 径の計測結果を示す。対象とする部品には直径の異な る多数の穴が開けられ, 寸法検査では, 各穴の直径と 中心位置を $0.1 \mathrm{~mm}$ の精度で計測することが要求され ている。測定精度と視野を考慮して, ライン合成画像 


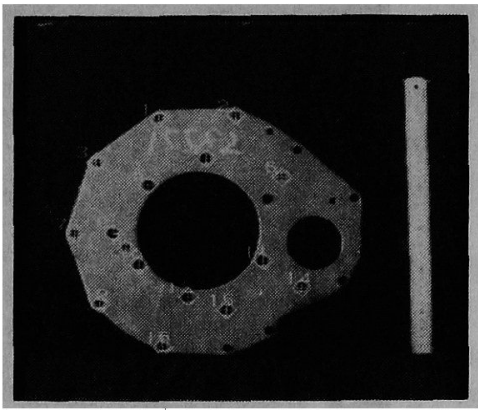

図 9 エリア画像（領域指定）

Fig. 9. An area image.

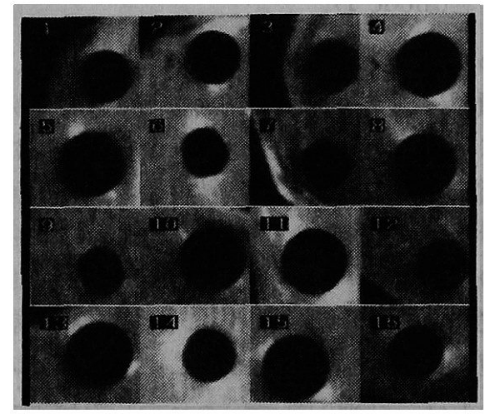

図 10 ライン合成画像 (モード 2)

Fig. 10. Example of a line scanning image (mode 2).

の 1 画素が約 $0.1 \mathrm{~mm}$ になるようにセンサは設置され ている。計測は表示メニューから処理手順を随時選択 することにより行われる。

まず，エリア画像を入力し高精度撮り込み領域の指 定を行う。エリア画像の各穴部の中心付近にカーソル を移動させその位置をポイントすると，撮り込み領域 が白枠で表示される。その際, ラインセンサ回転機構 を用いてラインセンサの機械走査軸を部品の姿勢に合 せる。既知の部品で測定箇所が既に登録してある場合 は，登録ファイル番号をカーソルで指示するだけで撮 り込み領域がエリア画面上に自動的に設定される。図 9 に示すように撮り込み領域がすべて正しい位置に設 定されたことを確認後, ラインセンサによる画像の撮 り込みを指示すると，機械走查が始まり，図 10 に示 すライン合成画像が約 10 秒後に表示される。

続いて, 得られた合成画像の二値化と境界抽出処理 を選択する。照明むらやシェーディングの影響を除く ため, 各領域ごとにしきい値を変え二值化を行う。二 值画像から各領域ごとに穴部の面積 $S$, 周囲長 $L$ の 画素数を計算し, 穴径 $D_{m}(=\sqrt{4 S / \pi})$ を求める。次い で, 円形度 $P\left(=4 \pi S / L^{2}>0.9\right)$ により究形状のチェッ
表 1 穴径計測結果の例

Table 1. Measurement of diameter of holes:

\begin{tabular}{r|c|c|r|r|r|c}
\hline No. & \multicolumn{2}{|c|}{$\begin{array}{c}\text { 面䅖 } \\
\text { (pixels) }\end{array}$} & $\begin{array}{c}\text { 周長 } \\
(\mathrm{mm})\end{array}$ & $\begin{array}{c}D_{a} \\
(\mathrm{~mm})\end{array}$ & $\begin{array}{c}\text { 誤差 } \\
(\mathrm{mm})\end{array}$ & $\begin{array}{c}\text { Pि 形 } \\
P\end{array}$ \\
\hline 1 & 2,882 & 199 & 8.9 & 9.0 & -0.1 & 0.915 \\
2 & 2,890 & 195 & 8.9 & 9.0 & -0.1 & 0.955 \\
3 & 2,876 & 200 & 8.9 & 8.2 & 0.7 & 0.904 \\
4 & 4,366 & 242 & 10.9 & 11.0 & -0.1 & 0.937 \\
5 & 4,442 & 246 & 10.9 & 11.0 & -0.1 & 0.922 \\
6 & 2,178 & 172 & 7.6 & 7.6 & 0 & 0.925 \\
7 & 2,606 & 187 & 8.3 & 8.2 & 0.1 & 0.936 \\
8 & 4,496 & 246 & 11.0 & 11.0 & 0 & 0.934 \\
9 & 2,260 & 173 & 7.9 & 8.0 & -0.1 & 0.949 \\
10 & 4,578 & 249 & 11.1 & 11.0 & 0.1 & 0.928 \\
11 & 4,378 & 240 & 10.9 & 11.0 & -0.1 & 0.955 \\
12 & 3,090 & 207 & 9.1 & 9.0 & 0.1 & 0.906 \\
13 & 4,548 & 246 & 11.0 & 11.0 & 0 & 0.944 \\
14 & 2,538 & 188 & 8.2 & 8.2 & 0 & 0.902 \\
15 & 4,520 & 245 & 11.0 & 11.0 & 0 & 0.946 \\
16 & 3,074 & 206 & 9.1 & 9.1 & 0 & 0.910 \\
\hline
\end{tabular}

クを行った後, 設計値との比較を行う。表 1 に穴径の 計測結果の例を示す。No. 3 の空径が設計穴径 $D_{a}$ と 明らかに異なっており，加工ミスであることが判明し た。現在, 画像入力から計測結果の出力までに要する 時間は約 30 秒であり, 従来の手作業による直接測定 に比較すると， $1 / 10$ 程度に時間短縮された。

以上に示した適用例から, 従来の画像入力装置ては 計測が困難であった大きな対象物の位置決めや寸法形 状計測が，本システムにより高精度かつ効率良く行兌 ることが示され，本方式の寸法形状計測への有用性加 確認された。

\section{6.むすび}

エリアセンサとラインセンサを一体化した複合視賞 センサシステムを開発し，機械部品などの寸法形戉を 高精度かつ効率良く計測する手法を提案した。すなわ ち, 対象物全体を分解能の粗いエリアセンサで高速に 撮り込み，寸法形状計測に必要な領域を抽出した後， エリアセンサより分解能が 7 倍高いラインセンサを回 転移動・機械走査して画像を撮り込み，この部分的容 高精度画像を用いることにより，寸法形状計測か效率 良く行えることを示した。本システムを機械部品の寸 法・形状計測に適用した結果, 従来法に比べ, 画像入 力時間は数分の一に, デー夕量は数十分の一に削堿さ れることが示され，本センサの有用性が明らかにな った。

本システムは局所的に精度を必要とする用途，例え ばパターン光投影法による三次元物体の形状計測に招 いても有用であると考えられる。今後は，計測時間の 
より短縮化を図ると共に, 部品の種別と姿勢をエリア 画像を用いて自動認識させ, 自動計測の可能なシステ ムに発展させて行きたい。

(平成元年 9 月 25 日受付)

\section{文献}

（1）江尻：工業用画像処理, p. 137 (昭63) 昭晃堂

（2）佐藤・井口：「液晶レンジファインダ一一液晶シャッ夕に よる高速距離画像計測システム—」, 信学論 (D), J71-D, 1249 (昭 63-7)

（3）成瀬・野村・山本：「スリット光による高精度距離・姿勢計 測」, 同上(D), J69-D, 1888 (昭61-12)

(4) H. Kono: "Moving robot applied mark tracking", Bridge Control Sci. Tech., 5, 2387 (1985)

（5）小郷・橋本・大平・桜井：「ライン CCD を用いた精細画像 抽出方式」, 信学論 (C), J65-C, 958 (昭 57)

（6）有賀・吉野・小郷・潔手・寺川：「極座標方式ライン CCD カメラの検捨」, 同上(C), 109, 394 (平元-5)

（7）岡田・今出・宮内・住本・麦田：「複合視覚センサーシステ 么の開発」, 第 3 回産業における画像センシングシンポジウ 么, p. 92 (昭 63)

（8）肥塚・平岡・中島・稲垣：「辞書学習機能を備えた一括画像 入力形高速キ一配列検榃装置」, 電学論 C, 108, 339 (昭 635)

（9）岡田・麦田：「画像処理用VME ボードの開発」, 第 2 回産 業における画像センシングシンボジウム, p. 5 (昭 62)

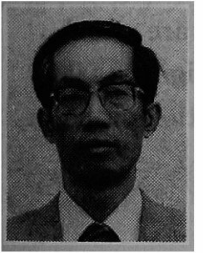

岡田三 郎 (正員)

昭和 23 年 11 月 30 日生。 49 年 3 月広島大学大学院工学研究科機械工 学専攻修士課程修了。同年 4 月通産 省工業技術院中国工業技術試験所に 入所, 現在に至る。主に，流体計測，画像を利用した 計測技術の研究に従事。計測自動制御学会, 日本機械 学会, 電子情報通信学会会員。

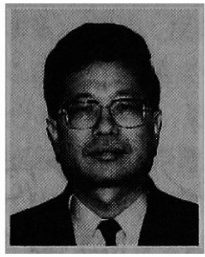

住 本 哲 宏 (正員)

昭和 16 年 4 月 30 日生。 42 年 3 月岡山大学大学院理学研究科修士課 程修了。シャープ(株)を経て，48 年通産省工業技術院中国工業技術試 験所に入所, 現在に至る。生産技術部システム工学研 究室長。工学博士。主に, 画像処理, データベースの 研究に従事。計測自動制御学会, 電子情報通信学会会 員。

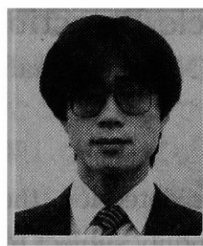

宮 内 秀 和 (非会員)

昭和 32 年 3 月 30 日生。 59 年九 州大学大学院総合理工学研究科博士 課程単位取得のうえ退学。同大学工 学部助手を経て，61 年通産省工業 技術院中国工業技術試験所に入所，現在に至る。主 に, システム制御, 画像処理の研究に従事。計測自動 制御学会, 日本機械学会, 電子情報通信学会会員。

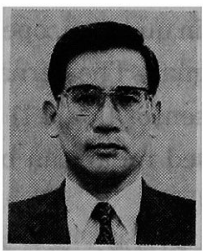

\section{山 本 秀 樹 (正員)}

昭和 19 年 1 月 2 日生。 41 年 3 月 岡山学工学部電気工学科卒業。同大 学助手, 同講師を経て, 63 年同大 学医療技術短期大学部助教授, 現在 に至る。工学博士。主に, 医用画像処理の研究に従 事。計測自動制御学会, 日本 $M E$ 学会, 電子情報通 信学会会員。 